\title{
Protective Effect of JXT Ethanol Extract on Radiation-Induced Hematopoietic Alteration and Oxidative Stress in the Liver
}

\author{
Xian-Zhe Dong, ${ }^{1}$ Yu-Ning Wang, ${ }^{2}$ Xiao Tan, ${ }^{1}$ Ping Liu, ${ }^{1}$ Dai-Hong Guo $\mathbb{D},{ }^{1}$ and Can Yan $(\mathbb{D})$ \\ ${ }^{1}$ Center of Drug Security, General Hospital of Chinese PLA, Beijing 100853, China \\ ${ }^{2}$ Department of Surgery, Chinese PLA General Hospital, Beijing 100853, China \\ ${ }^{3}$ Department of Basic Theory of Chinese Medicine, School of Pre-Clinical Medicine, Guangzhou University of Chinese Medicine, \\ Guangzhou 510060, China \\ ${ }^{4}$ The Research Centre of Basic Integrative Medicine, Guangzhou University of Chinese Medicine, Guangzhou 510060, China
}

Correspondence should be addressed to Dai-Hong Guo; guodh301@163.com and Can Yan; yancan999@sina.com

Received 26 April 2018; Revised 1 August 2018; Accepted 4 September 2018; Published 28 October 2018

Academic Editor: Alexandros Georgakilas

Copyright (c) 2018 Xian-Zhe Dong et al. This is an open access article distributed under the Creative Commons Attribution License, which permits unrestricted use, distribution, and reproduction in any medium, provided the original work is properly cited.

\begin{abstract}
This study aims at investigating the radioprotective effect of ethanol extract from Ji-Xue-Teng (JXT, Spatholobus suberectus) on radiation-induced hematopoietic alteration and oxidative stress in the liver. Mice were exposed to a single acute $\gamma$-radiation for the whole body at the dose of $6.0 \mathrm{~Gy}$, then subjected to administration of amifostine $(45 \mathrm{mg} / \mathrm{kg})$ or JXT ( $40 \mathrm{~g}$ crude drug/ $/ \mathrm{kg}$ ) once a day for 28 consecutive days, respectively. Bone marrow cells and hemogram including white cells, red cells, platelet counts, and hemoglobin level were examined. The protein expression levels of pJAK2/JAK2, pSTAT5a/STAT5a, pSTAT5b/ STAT5b, and Bcl-2 in bone marrow tissue; levels of reactive oxygen species (ROS); and the activity of superoxide dismutase (SOD), malondialdehyde (MDA), and glutathione peroxidase (GSH-Px) in serum and liver tissue were determined. At the end of the experiment, the effect of JXT on cell viability and G-CSF and G-CSFR levels in NFS-60 cells were tested by CCK- 8 assay, ELISA, and flow cytometry. The results showed that the mice exposed to $\gamma$-radiation alone exhibited a typical hematopoietic syndrome. In contrast, at the end of the 28-day experiment, irradiated mice subjected to oral administration of JXT showed an obvious improvement on blood profile with reduced leucopenia, thrombocytopenia (platelet counts), RBC, and hemoglobin levels, as well as bone marrow cells. The expression of pJAK2/JAK2, pSTAT5a/STAT5a, and Bcl-2 in bone marrow tissue was increased after JXT treatment. The elevation of ROS was due to radiation-induced toxicity, but JXT significantly reduced the ROS level in serum and liver tissue, elevated endogenous SOD and GSH-PX levels, and reduced the MDA level in the liver. JXT could also increase cell viability and G-CSFR level in NFS-60 cells, which was similar to exogenous G-CSF. Our findings suggested that oral administration of JXT effectively facilitated the recovery of hematopoietic bone marrow damage and oxidative stress of the mice induced by $\gamma$-radiation.
\end{abstract}

\section{Introduction}

Radiotherapy is widely used in cancer treatment. Although irradiation is targeted at malignant tissues, the surrounding normal tissues or organs are also affected [1-3]. Wholebody radiation may result in acute radiation syndrome with profound pathophysiological consequences characterized as severe suppressed hematopoiesis, gastrointestinal injury, cerebrovascular system, and neurological damage [4-7]. The hematopoietic system is exceedingly sensitive to ionizing radiation, with an associated decrease in bone marrow cells (BMC) and circulating peripheral blood cells that may further cause anemia, bleeding, infection, and declined immune function $[8,9]$. According to previous reports, oxidative damage to DNA can be a result from radiation-induced free radicals or ROS [10]. The ionizing radiation at a relatively high level can lead to changed gene expression pattern and mutation prevalence and blunt the repairing mechanisms of DNA 
damage $[11,12]$. The development of efficacious radioprotectors to accelerate hematopoiesis recovery should be a valuable contribution to radiation oncology.

As a consequence, it is essential to search radioprotectors to control side effects in both planned exposure such as radiotherapy and unplanned exposure such as natural radiation [13]. Although synthetic compounds including thiols, baminothiols, thiadiazoles, or benzothiazoles reveal certain radioprotective effects, their side effects have also gained extensive attention [14]. Amifostine is the only agent approved so far by the Food and Drug Administration for treating radiation syndrome [15]. However, amifostine gives rise to significant adverse reactions in many cases; for example, a phase III clinical trial has found its adverse reactions in $41 \%$ of head and neck cancer patients, with symptoms including hypotension, hypocalcemia, nausea, vomiting, and allergy [16]. Therefore, it is a promising strategy to develop natural radioprotectors from plants and herbs [17, 18]. Herb-derived phytochemicals offer opportunities to develop efficacious radioprotective agents due to low toxicity and few side effects [19-21]. Recently, natural compounds such as genistein or ginsan from plant extracts have been extensively explored to have strong capacity to alleviate radiationinduced damage $[2,22]$.

Ji-Xue-Teng (JXT) is a traditional herb from the dry rattan of Spatholobus suberectus (S. suberectus) Dunn, recorded in Gang $\mathrm{Mu}$ Shi Yi as a holy drug of the blood, which can remove blood clot and produce fresh blood. Modern pharmacological researches have documented that JXT and its active components are widely used for improving blood circulation and executing anti-inflammation, antibacterial, neuroprotective, antioxidative, and anticancer effects [23-25]. According to our previous report, the bioactive components of JXT can promote the proliferation of hematopoietic progenitor cells (HPC) in bone marrowdepressed mice [26], but the impact and underlying molecule mechanism of JXT on irradiation-induced hematological toxicity and other organ injury are still unclear. In the present study, the effect of JXT on 6.0 Gy $\gamma$-radiationinduced myelosuppression and oxidative damage of the liver tissues in mice and the underlying hematopoietic mechanisms were explored.

\section{Materials and Methods}

2.1. Chemicals. JXT was purchased from Beijing Lvye Pharmaceutical Co. Ltd. (Beijing, China), Fujian (China) origin. JXT was cut into small pieces and soaked in $75 \%$ ethanol at 8 times volume overnight and then extracted 3 times with $1 \mathrm{~h}$ for each time. Finally, the filtrates were mixed and concentrated by a rotary evaporator with bath temperature lower than $40^{\circ} \mathrm{C}$. Ethanol extract was lyophilized to powder.

The reagents and kits for determining enzyme activity were purchased from Nanjing Jiancheng Bioengineering Institute (NJBI, Nanjing, China). The antibodies for evaluating G-CSFR, Bcl-2, JAK2, pJAK2, STAT5a, pSTAT5a, STAT5b and pSTAT5b were purchased from Abcam (Abcam, USA). Amifostine was purchased from Dalian Merro Pharmaceutical Factory (Dalian, China); RPMI-1640 culture medium and fetal bovine serum (FBS) were purchased from HyClone (HyClone, USA). G-CSF ELISA kit was purchased from Shanghai Tongwei Biotech Co. Ltd. (Shanghai, China).

2.2. Animals. A total of 40 Chinese Kun Ming (KM) mice with the age of 6-8 weeks and inbred colony were purchased from the Laboratory Animal Breeding and Research Center in PLA General Hospital, Beijing, China, and maintained under controlled conditions of temperature $\left(23 \pm 2^{\circ} \mathrm{C}\right)$ and light (12L:12D). All mice were provided with standard chow diet and water ad libitum.

2.3. Irradiation and Administrations. Gamma radiation ( $\gamma$-radiation) at the dose of $6 \mathrm{~Gy}$ was delivered in the Department of Radiotherapy and Oncology, the Military Medical Academy of Science. The mice were randomly divided into 4 groups including nonirradiation control, irradiation control, positive treatment control, and JXT treatment groups with 10 mice in each group. The mice from the positive treatment control group were administrated with amifostine at $43.6 \mathrm{mg} / \mathrm{kg}$ by tail vein injection [27], and the mice from the JXT treatment group were orally administrated with JXT ethanol extract at the dose of $40 \mathrm{~g} / \mathrm{kg}$ based on the amount of crude drug. JXT was dissolved in sterile saline and orally administrated for 21 consecutive days after mouse irradiation.

2.4. Hematological Analysis. The effect of JXT extract on the peripheral blood of mice from each experiment group was analyzed. On day 21 after irradiation, hemoglobin (HGB) level, erythrocyte (RBC) count, total leukocyte (WBC) count, and platelet (PLT) count for each mouse were measured at 0 day (before irradiation) and 21 days postirradiation using an automated hematology analyzer (BC-2800vet; Mindray, China).

2.5. Antioxidant Activity. The ROS level in the serum and ROS, SOD, GSH-Px, and MDA levels in the liver tissue were analyzed, respectively, according to the instructions of the kits from the manufacturer.

2.6. Bone Marrow Cell Counting. Bone marrow cells were collected from both femurs of each mouse at day 10 after whole-body radiation at the dose of $6 \mathrm{~Gy}$. The collected bone marrow cells were rinsed with PBS, and single-cell suspension was obtained. After the lysis of red blood cells, the bone marrow cells were suspended in RPMI-1640 with 10\% fetal bovine serum (FBS) and $100 \mathrm{U} / \mathrm{ml}$ antibiotics. Then, the bone marrow cells were counted in a hemacytometer under an optical microscope to determine whether JXT extract can protect the bone marrow cells from the depletion induced by $\gamma$-radiation.

2.7. Western Blot. The preparation of bone marrow cells was the same as above. For western blot analysis, total protein was extracted first, and cells were washed twice with cold PBS and lysed in the radioimmunoprecipitation assay (RIPA) buffer (20 mM Tris- $\mathrm{HCl}, \mathrm{pH} 7.5 ; 150 \mathrm{mM}$ sodium chloride; $1 \%$ Triton; $1 \mathrm{mM}$ EGTA; $1 \mathrm{mM}$ EDTA; $2.5 \mathrm{mM}$ sodium 


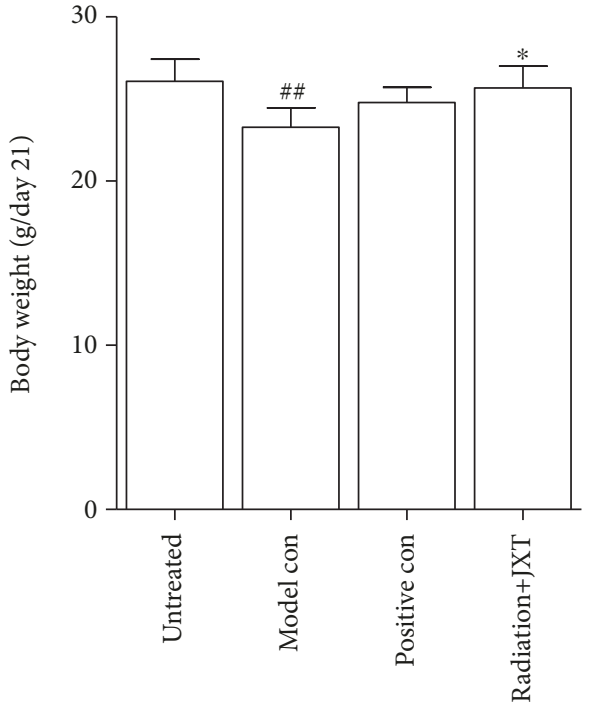

(a)

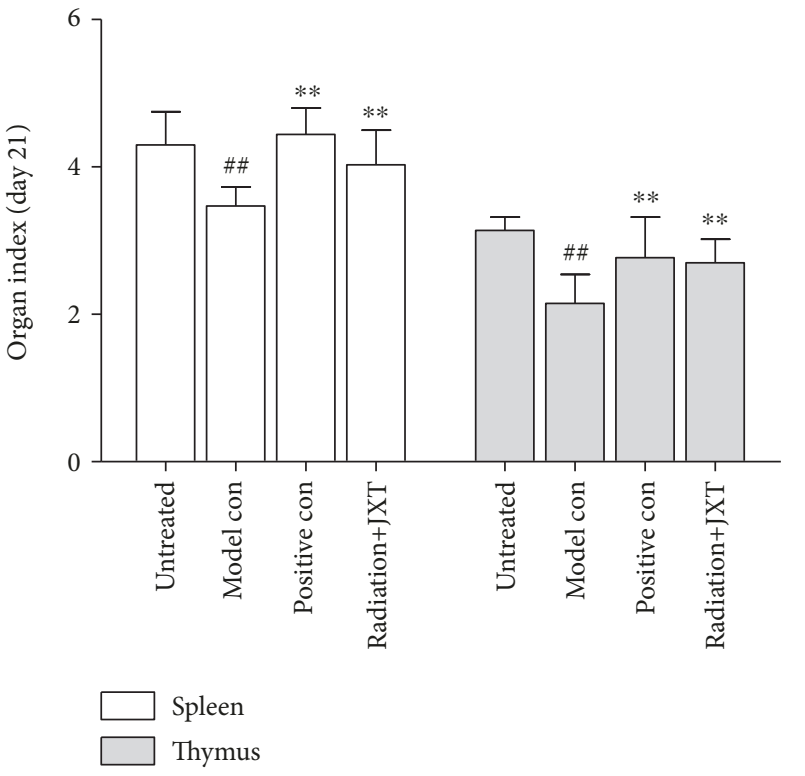

(b)

FIGURE 1: Effect of JXT on body weights of $\mathrm{Co}^{60}$-irradiated mice. All data were expressed as mean \pm SEM $(n=10)$. ${ }^{\#} P<0.05$; ${ }^{\# \#} P<0.01$ when compared with the untreated control group. ${ }^{*} P<0.05$; ${ }^{* *} P<0.01$ when compared with the $\mathrm{Co}^{60}$-irradiated group. (a) Body weight; (b) organ index.

pyrophosphate; $1 \mathrm{mM} \beta$-glycerophosphate; $1 \mathrm{mM}$ sodium orthovanadate; $1 \mu \mathrm{g} / \mathrm{ml}$ leupeptin; and $1 \mathrm{mM} \mathrm{PMSF)} \mathrm{for}$ $20 \mathrm{~min}$ on the ice. After centrifugation at $12000 \times \mathrm{g}$ for 10 min, protein was then quantitated by using a bicinchoninic acid protein assay kit (Bioworld Technology, USA). After being heated at $95^{\circ} \mathrm{C}$ for $8 \mathrm{~min}$, the samples were loaded on $12 \%$ SDS-polyacrylamide gel for electrophoresis and transferred to PVDF membrane (Millipore, Billerica, MA). The membrane was blocked for $2.5 \mathrm{~h}$ in TBS-T buffer $(10 \mathrm{mM}$ Tris, $\mathrm{pH}$ 8.0, $150 \mathrm{mM} \mathrm{NaCl}$, and $0.1 \%$ Tween-20) containing $3 \%(w / v)$ bovine serum albumin (BSA; Sigma-Aldrich, USA) at room temperature and then probed with each primary antibody (1:500 dilution) at $4^{\circ} \mathrm{C}$ overnight. After washing with TBS-T for three times, the membrane was then incubated with appropriate horseradish peroxidase-labeled secondary antibody for $2 \mathrm{~h}$ at room temperature. For quantitative analysis of immunoblot bands, the densities of the bands were measured by scanning densitometry (Bio-Rad, Hercules, CA). All experiments were repeated at least three times.

2.8. Cell Culture. NFS-60 cell line, derived from murine myeloid leukemia, is responsive to different growth factors including G-CSF. Cells were maintained in RPMI 1640 medium supplemented with $10 \% \mathrm{FBS}, 50 \mathrm{U} / \mathrm{ml}$ penicillin, $50 \mu \mathrm{g} / \mathrm{ml}$ streptomycin, and $15 \mathrm{ng} / \mathrm{ml} \mathrm{G-CFS} \mathrm{(Sigma,} \mathrm{USA).}$

2.9. Cell Viability Detection by CCK-8 Assay. NFS-60 cell viability after JXT treatment was evaluated with CCK-8 assay. Cells (3000 cells/well) were plated in 96-well plates. After $24 \mathrm{~h}$ culture, JXT at different final concentrations $(1.6,8,40$, and $200 \mathrm{~g} / \mathrm{ml}$ ) was added into the plates and detected after
$24 \mathrm{~h}$ culture. Briefly, $20 \mu \mathrm{l}$ of CCK- 8 solution was added to the culture medium and incubated at $37^{\circ} \mathrm{C}$ for $4 \mathrm{~h}$. Then, the OD was spectrophotometrically measured at $450 \mathrm{~nm}$ using a microplate spectrophotometer (1420 Victor $^{3}$, Perkin-Elmer, USA). Viability was expressed as the percentage of vehicle-treated (basal) culture that was set to $100 \%$.

2.10. Enzyme-Linked Immunosorbent Assay. Culture media were collected following treatments and promptly stored at $-80^{\circ} \mathrm{C}$ until the future assay. The G-CSF level was measured using commercially available paired antibody quantitative ELISA kit according to the manufacturer's instructions. Data were expressed as $10^{-6} \mu \mathrm{g} / \mathrm{ml}$. Dispensed antigen standards and samples were added to each well of 96-well plates precoated with primary antibodies. After adding biotin conjugate reagent and enzyme conjugate reagent into each well, the plates were incubated at $37^{\circ} \mathrm{C}$ for $30 \mathrm{~min}$. Then, the plates were rinsed with distilled water for 5 times and measured using a microtiter plate reader (Perkin-Elmer, USA).

2.11. Flow Cytometric Detection of G-CSFR. The G-CSFR level in cells was measured using flow cytometry. A total of $5 \times 10^{6}$ NFS-60 cells were plated in 6-well plates for each well. After treatment with JXT at different final concentrations $(1.6,8,40$, and $200 \mu \mathrm{g} / \mathrm{ml})$ for $24 \mathrm{~h}$, the cells were harvested and washed in PBS and then centrifuged at $1000 \times g$ for $5 \mathrm{~min}$. The cell pellet was resuspended at the density of $5 \times 10^{6}$ cells $/ \mathrm{ml}$ and incubated with G-CSFR antibody for $30 \mathrm{~min}$ at $37^{\circ} \mathrm{C}$. Then, the cells were washed in PBS and incubated with IgG secondary antibody for $30 \mathrm{~min}$ at $37^{\circ} \mathrm{C}$. The cells were then analyzed in a Becton Dickinson flow 


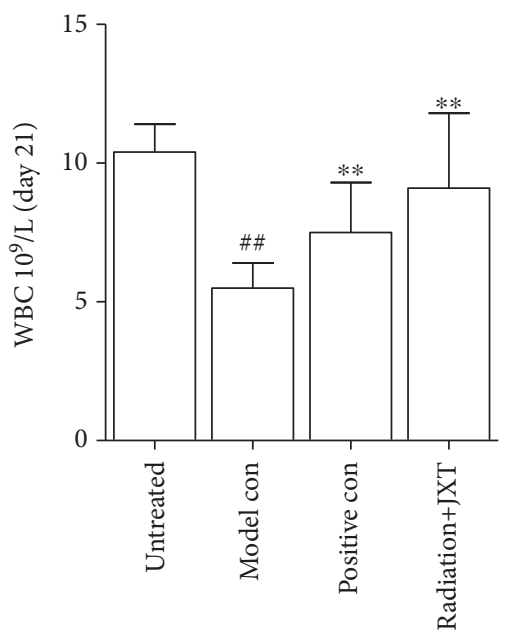

(a)

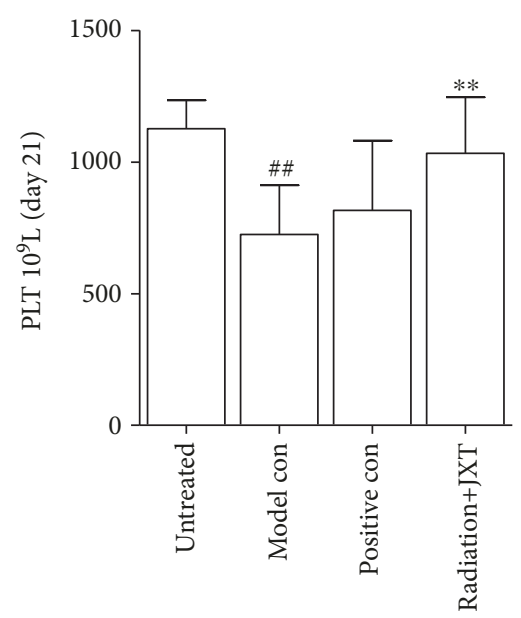

(c)

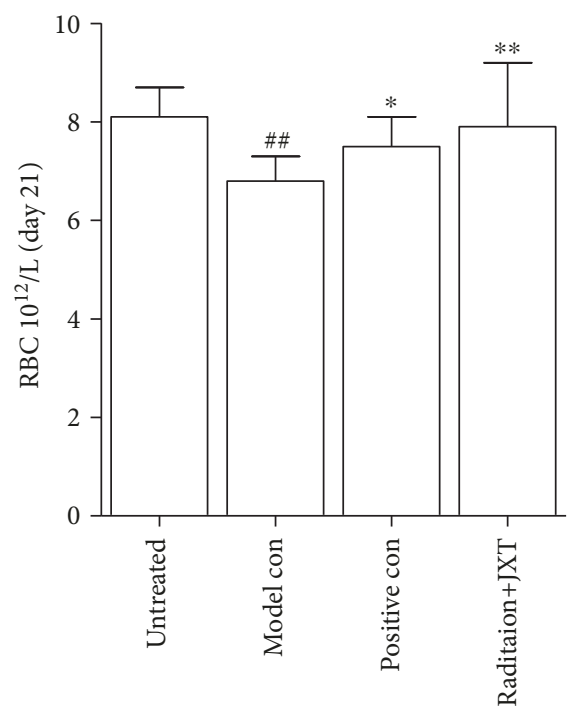

(b)

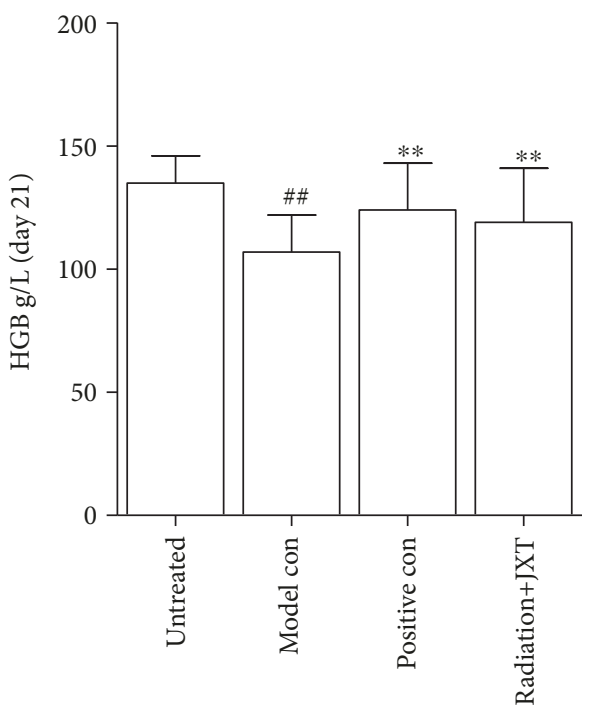

(d)

FIGURE 2: Effect of JXT on the number of circulating peripheral blood cells in $\mathrm{Co}^{60}$-irradiated mice. All data were expressed as mean \pm SEM $(n=10)$. ${ }^{\#} P<0.05$; ${ }^{\#} P<0.01$ when compared with the untreated control group. ${ }^{*} P<0.05 ;{ }^{*} P<0.01$ when compared with the Co ${ }^{60}$ irradiated group. (a) White blood cell (WBC) number; (b) red blood cell (RBC) number; (c) platelet (PLT) number; (d) hemoglobin (HGB) level.

cytometer (Becton, Dickinson and Company, USA). Each sample was collected at the amount of ten thousand cells.

\section{Statistical Analysis}

All data were expressed as mean \pm standard deviation $(\mathrm{M} \pm \mathrm{SD})$. Statistical analysis was conducted by using SPSS 16.0 software. One-way analysis of variance (ANOVA) followed by Tukey's post hoc test was used for multiple group comparisons. The statistically significant difference was considered at $P<0.05$.

\section{Results}

4.1. Effect of JXT Treatment on the Loss of Body Weights and Organ Indexes. Figure 1 demonstrated the changes of body weights, spleen index, and thymus index in each group at day 21 . There was a profound loss in body weight, spleen index, and thymus index of the animals exposed to $6.0 \mathrm{~Gy}$ $\gamma$-radiation. The administration with JXT significantly increased the body weight $(P<0.05)$, spleen index, and thymus index $(P<0.01)$ when compared to the radiation group. The results suggested that JXT administration played a positive role in preventing radiation-induced loss of body weight, spleen index, and thymus index of the mice.

4.2. Effect of JXT Treatment on Peripheral Blood Cells. WBC counts of the mice before and after irradiation were shown in Figure 2(a). Total WBC counts in irradiated animals were determined to be significantly reduced at day $21(P<0.01)$ when compared with those in the control group. The administration with JXT and amifostine could attenuate the 


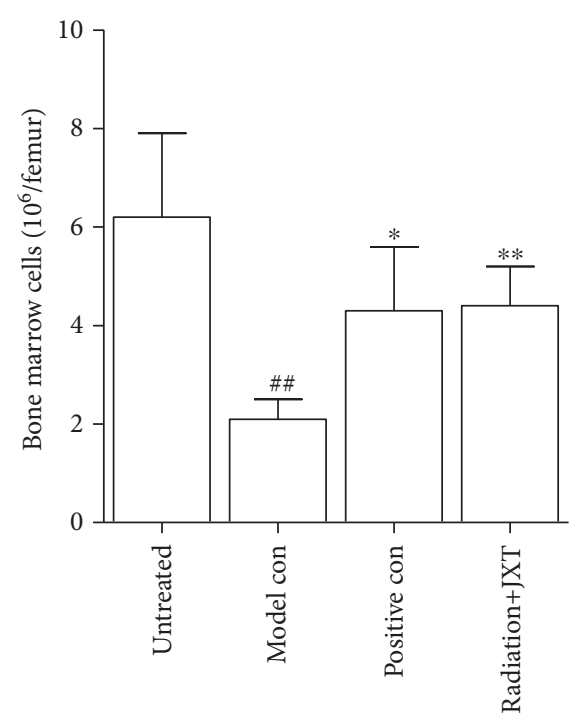

FIGURE 3: Effect of JXT on the number of bone marrow cells in $\mathrm{Co}^{60}$-irradiated mice. All data were expressed as mean $\pm \mathrm{SEM}$

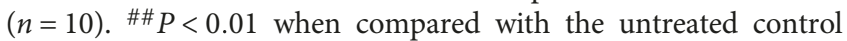
group. ${ }^{*} P<0.05 ;{ }^{* *} P<0.01$ when compared with the $\mathrm{Co}^{60}$ irradiated group.

decrease in WBC counts. Figure 2(b) showed that irradiation reduced the $\mathrm{RBC}$ number at day 21 , while a significant increase in the RBC number was observed on day 21 in the JXT-treated mice $(P<0.01)$ and amifostine-treated mice $(P<0.05)$. As shown in Figure $2(\mathrm{c})$, the number of peripheral PLT decreased markedly after irradiation, and the PLT decline was significantly attenuated by JXT on day 21 in comparison to the radiation group $(P<0.01)$. Figure $2(\mathrm{~d})$ showed that irradiation reduced the HGB level at day 21; in contrast, a significant increase in the HGB level was observed on day 21 in the JXT- and amifostine-treated mice $(P<0.01$ and 0.05$)$. These results showed that the mice exposed to $\gamma$-radiation alone exhibited a typical hematopoietic syndrome. On the other hand, at the end of the 21-day experiment, irradiated mice receiving oral administration of JXT showed an improved blood profile with reduced leucopenia, thrombocytopenia (platelet counts), RBC, and hemoglobin levels.

4.3. Effect of JXT Treatment on the Depletion of Bone Marrow Cells. Subsequently, the potential of JXT to protect irradiation-induced damage of bone marrow cells was also investigated. The effect of JXT on hematopoietic tissue in irradiated mice was evaluated by $\mathrm{HE}$ staining in our previous study [28]. The marrow cellularity in the radiation group was decreased when compared with that in the naive group. Although the irradiation can result in a continuous increase in the number of adipocytes [29], JXT treatment could significantly increase the total number of bone marrow cells and ameliorate cellular contents of the bone marrow (Figure 3, $P<0.01)$.

4.4. Effect of JXT Treatment on the Expression of Proteins in JAK/STAT Signal Pathway. In order to identify whether JAK/STAT signal pathway can be activated by JXT, we examined the phosphorylation of JAK2, STAT5a, and STAT5b in the bone marrow after JXT treatment. The expression of pJAK2/JAK2 and pSTAT5a/STAT5a in bone marrow tissue was decreased after radiation, and the expression of phosphor-JAK2 and phosphor-STAT5a was enhanced. But the expression of pSTAT5b/STAT5b was not changed after radiation and JXT treatment (Figure 4).

4.5. Effect of JXT Treatment on the Proliferation, G-CSF, and G-CSFR of NFS-60 Cells. The CCK-8 assay was used to evaluate the effect of JXT on the viability of NFS-60 cells. The cells treated with G-CSF $(15 \mathrm{ng} / \mathrm{ml})$ revealed an obvious increase in the percentage of viable cells when compared to the control group. After JXT treatment at different concentrations $(6 \mu \mathrm{g} / \mathrm{ml}$ to $40 \mu \mathrm{g} / \mathrm{ml})$, the viability of NFS- 60 cells was increased in a concentration-dependent manner $(P<0.05$ or $P<0.01)$. However, the viability of NFS-60 cells in the $200 \mu \mathrm{g} / \mathrm{ml}$ treatment group was suppressed (Figure 5(a)). At the same time, we measured the G-CSF level in the same conditioned media by ELISA. Only $15 \mathrm{ng} / \mathrm{mlG}$-CSF could induce the release of G-CSF $(P<0.01)$, but no change in the JXT treatment groups (Figure 5(b)). Flow cytometry showed that JXT treatment at $6-200 \mu \mathrm{g} / \mathrm{ml}$ could also increase the G-CSFR level in NFS-60 cells (Figures 5(c)-5(i)).

4.6. Effect of JXT Treatment on ROS, SOD, GSH-Px, and $M D A$ in the Serum and Liver. We next investigated whether JXT can regulate oxidative stress system in mice under radiation. JXT treatment significantly reduced the ROS level that was elevated due to radiation-induced toxicity in the liver and serum (Figures 6(a) and 6(b)) and improved endogenous SOD and GSH-Px levels, as well as reduced MDA level in the liver (Figures 6(c)-6(e)).

4.7. Effect of JXT Treatment on Bcl-2 Expression in the Bone Marrow. In order to explore the effect of JXT on the apoptosis of bone marrow cells from mice upon $\gamma$-radiation, we evaluated the expression levels of $\mathrm{Bcl}-2$ protein before and after JXT treatment. As shown in Figure 7, the expression of Bcl-2 was significantly declined in the radiation-treated mice, and JXT could increase the expression of Bcl-2 in bone marrow tissue significantly $(P<0.01)$.

\section{Discussion}

The bone marrow is the most important hematopoietic organ with hematopoietic cells at different developmental stages. A high proliferation rate of bone marrow cells is highly susceptible to irradiation-induced injury [30]. Bone marrow injury can cause the suppression of hematopoiesis, thus resulting in the low number of circulating blood cells and undesirable side effects such as anemia, bleeding, and infection $[31,32]$. We previously demonstrated the protection of bioactive components in JXT against radiation-induced bone marrow damage [26], and herein we have applied an irradiationinduced myelosuppressed mouse model to investigate the protection potential of ethanol extract from JXT on radiation-induced hematological toxicity. Results showed that the administration with JXT could ameliorate $\mathrm{Co}^{60}$ 


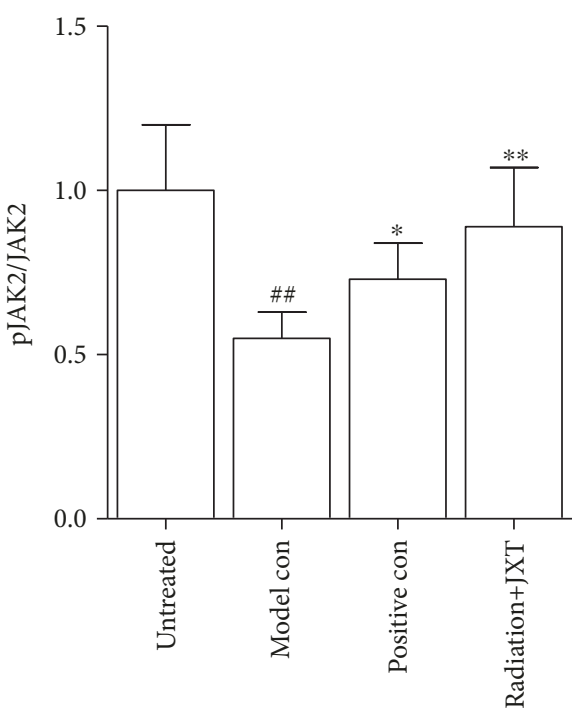

(a)

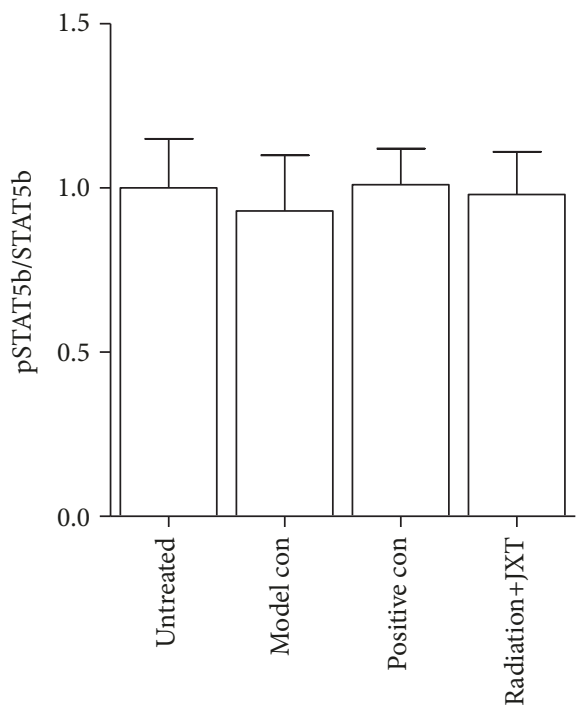

(c)

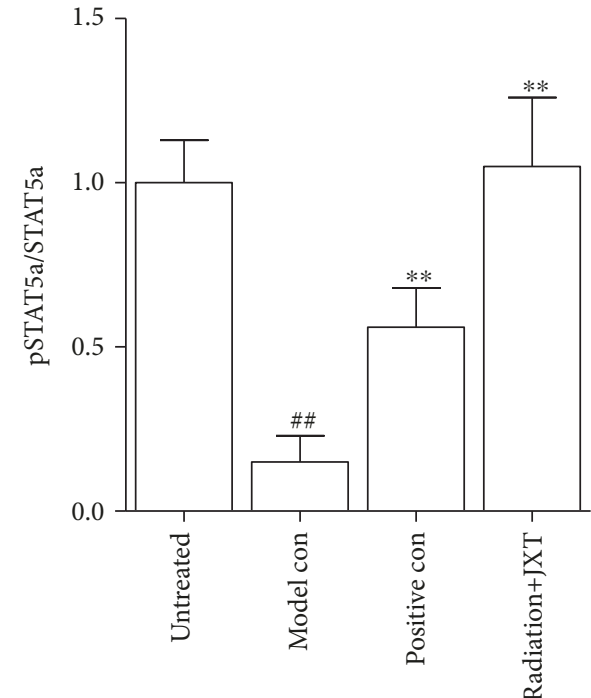

(b)

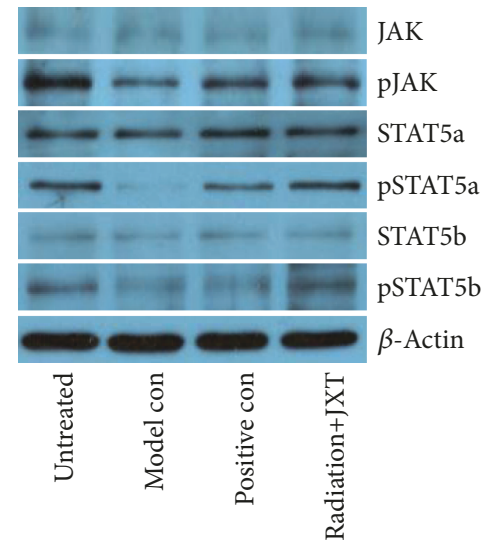

(d)

FIgURE 4: Effect of JXT on the phosphorylation of JAK2, STAT5a, and STAT5b in $\mathrm{Co}^{60}$-irradiated mice. All data were expressed as

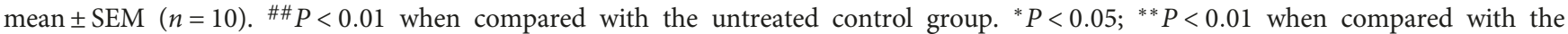
$\mathrm{Co}^{60}$-irradiated group.

irradiation-induced damage and significantly increase the number of peripheral blood cells (WBC, RBC, and PLT), body weight, spleen index, thymus index, and bone marrow cells. Together, these results confirm the enhancement of JXT on hematopoiesis.

Normally, the peripheral blood cell number maintains relative stability, depending on the hematopoietic function of the bone marrow [33]. Radiation exposure can cause injury in hematopoiesis and can result in peripheral blood cell cytopenia and the decrease in mature RBC in anemia. The decreased PLT can lead to bleeding, and the decreased WBC can result in infection [5]. Our results demonstrate that $\mathrm{Co}^{60}$ irradiation significantly reduced WBC and PLT counts in the peripheral blood of the mice; however, JXT administration can accelerate the recovery of peripheral blood cells. In order to investigate the effect of JXT treatment on bone marrow injury, the analysis of BMC counts indicated that $\mathrm{Co}^{60}$ irradiation significantly decreased the BMC number, and JXT treatment attenuated this reduction, suggesting that JXT may accomplish the protection by improving the density of BMC and increasing the number of nucleated cells in the bone marrow of irradiated mice.

In the present study, we confirmed the radioprotective effect of JXT extract in the hematopoietic system in vivo and in vitro, and the alcohol extract of JXT can promote protein phosphorylation and the activation of JAK2STAT5 signal pathway, thereby promoting hematopoiesis. The regulation of hematopoiesis involves multiple signal transduction pathways, in which the JAK-STAT signal pathway is an important signal pathway for the signal transduction of hematopoietic growth factors [34, 35]. Receptor dimerization induced by cytokine and receptor 


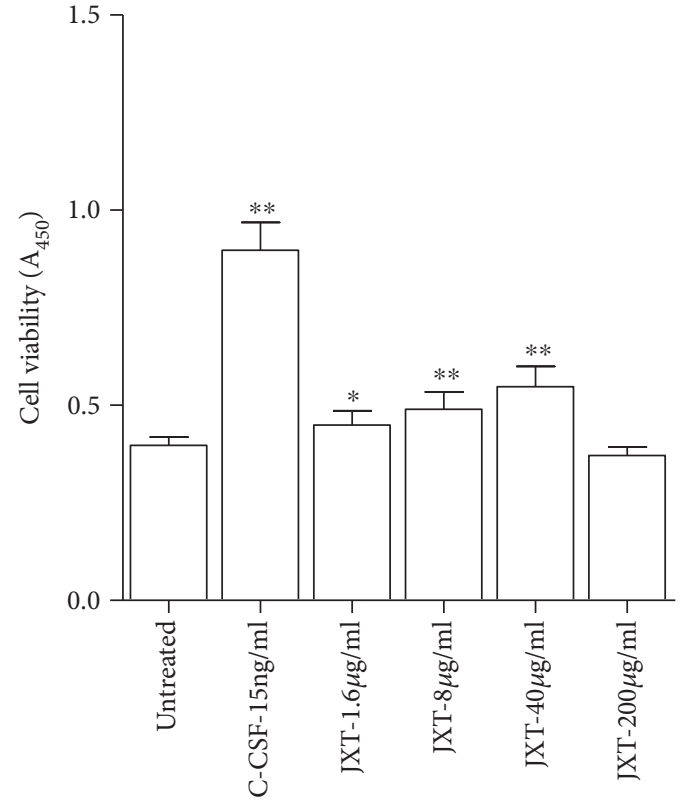

(a)

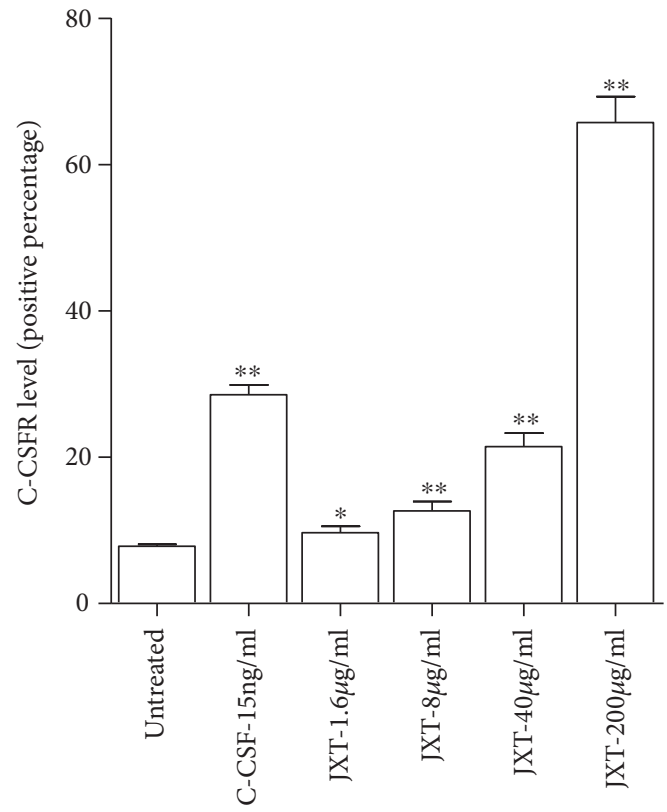

(c)

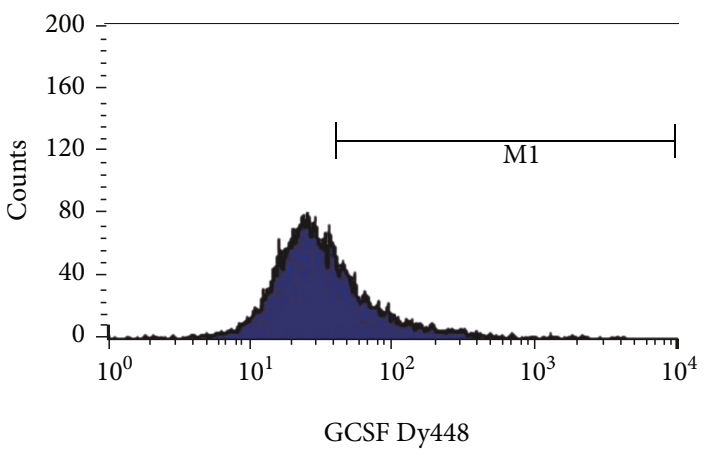

(e)

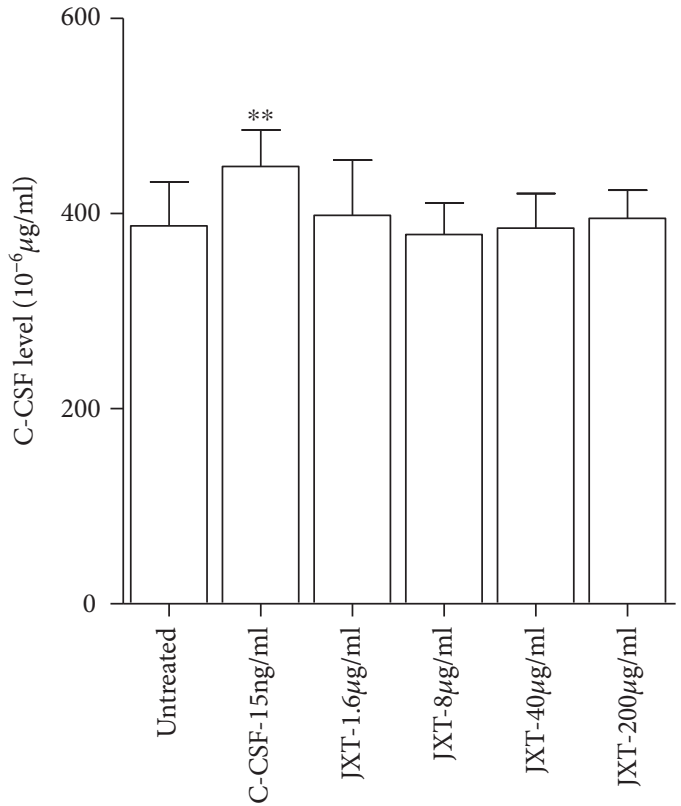

(b)

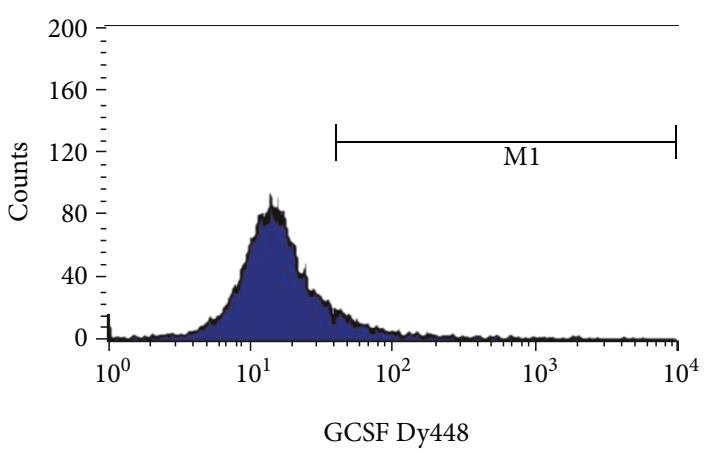

(d)

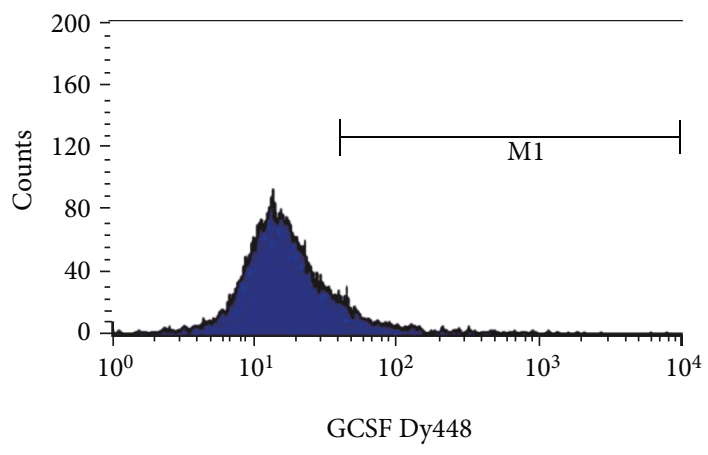

(f)

Figure 5: Continued. 


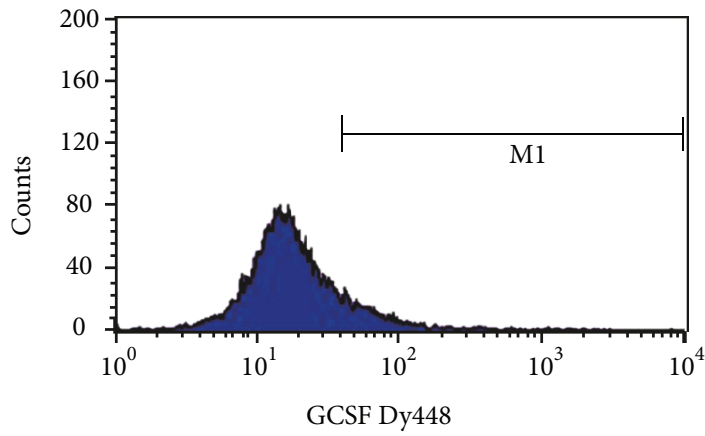

(g)

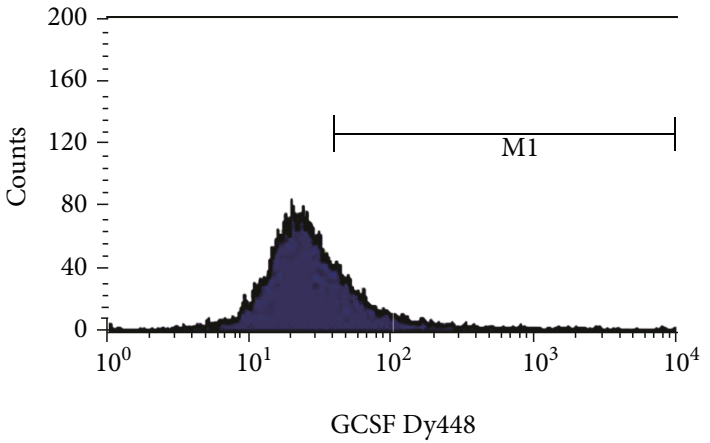

(h)

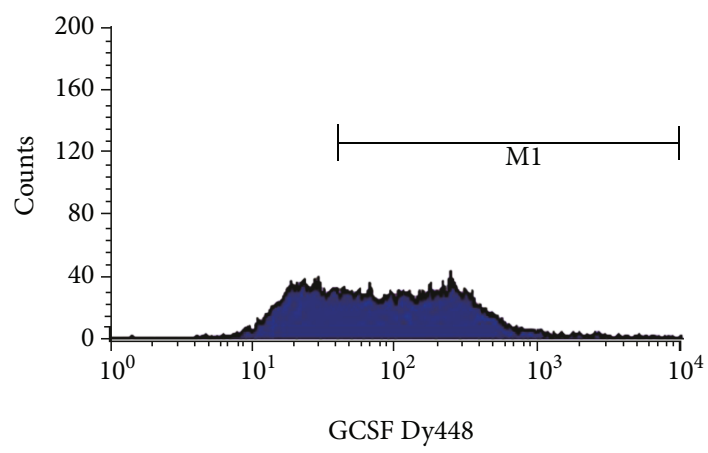

(i)

FIGURE 5: Effect of JXT on cell viability and G-CSF and G-CSFR levels in NSF-60 cells. All data were expressed as mean \pm SEM $(n=3)$. ${ }^{*} P<0.05 ;{ }^{* *} P<0.01$ when compared with the untreated control group.

binding can lead to JAK phosphorylation and initiate signal transduction. The activated JAK then catalyzes substrate proteins such as STAT, transmits the information to nuclei, and regulates gene expression, cell proliferation, and differentiation [36-38]. The signal transduction of G-CSF and GM-CSF receptors can be completed through the JAK2-STAT5 signal pathway [39].

In our studies, Bcl-2 was decreased after radiation treatment and increased in JXT-treated mice. The signal transducer and activator of transcription 5 (STAT5) are a critical regulator of normal and leukemic lymphomyeloid development through activating downstream early-acting cytokines, their receptors, and Janus kinases (JAKs) [40-43]. STAT5mediated regulation of $\mathrm{Bcl}-2$ in hematopoietic cells has been reported both in mouse [44] and in human hematopoietic cells [45]. STAT5ab $\mathrm{av}^{\Delta \mathrm{N} / \Delta \mathrm{N}}$ mast cells have a reduced level of $\mathrm{Bcl}-2$ expression. $\mathrm{Bcl}-2$ is a bona fide direct target of STAT5 so that STAT5 requires the $\mathrm{N}$-domain for the suppression of miR15/16, induction of Bcl-2, and induction of survival signaling in mast cells and myeloproliferative neoplasms (MPNs) [46, 47]. The overexpression of Bcl-2 increases both stem cell number and repopulation potential [48-50]. Bcl-2 also has the antiapoptotic function so that the deficient survival function of BMC can be restored by adding Bcl-2 after JXT treatment.

Ionizing radiation can produce free radicals in cells, such as superanion, hydroxyl, and hydrogen peroxide free radicals [51]. The activity of free radicals can directly or indirectly damage the cell membrane and nucleic acid in the body, thus causing DNA strand breaks and the changes in tissue morphology and metabolism function, enzyme activity, and microcirculation. If free radicals are not timely removed, they could result in more serious physical or chemical injury [52, 53]. Radiation-induced liver injury often occurs in abdominal and pelvic tumors. The radiation-induced injury of the liver results in cell degeneration, apoptosis and necrosis, disordered enzyme activity, biofilm destruction, metabolic disorders, and severe functional failure of liver. Under normal circumstances, free radicals in the human body are in the dynamic balance of continuous production and scavenging. The scavenging of free radicals is mainly dependent on the action of antioxidant enzymes. SOD is a metal enzyme widely existed in organic organisms. It has super antioxidant function and can catalyze disproportionation of free radicals and scavenge free radicals, so as to protect damaged cells and maintain dynamic balance of oxidation and antioxidant reactions. MDA is the degradation product of lipid peroxide, and it has an attack on body cells. The content of MDA can reflect the extent of lipid peroxidation and indirectly reflect the damage of cells. The interaction of MDA and SOD has demonstrated that SOD activity can indirectly reflect the scavenging capacity of oxygen free radicals. MDA content can indirectly reflect free radical-induced damage degree. In the present study, JXT could regulate the oxidative stress system of mice under radiation, suggesting that JXT can protect the liver from oxidative damage induced by radiation.

Many natural products and compounds have been found to have radioprotective effects. A novel lignin-derived polyphenolic composition with ammonium molybdate, BP-C2 mitigates radiation-induced damage in midlethal range of 


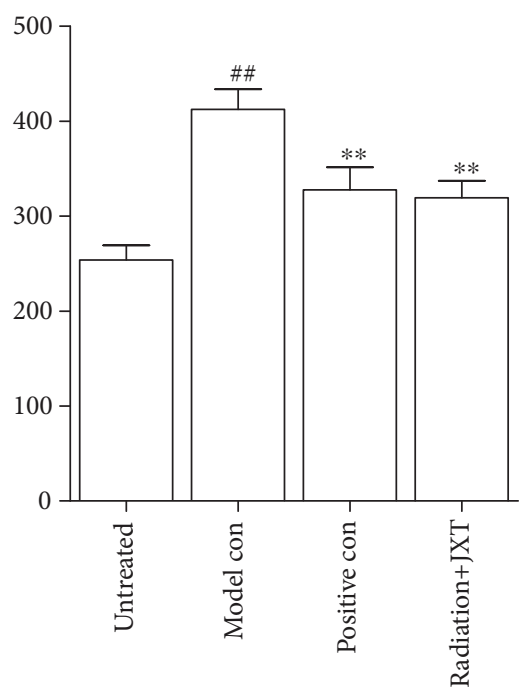

(a)

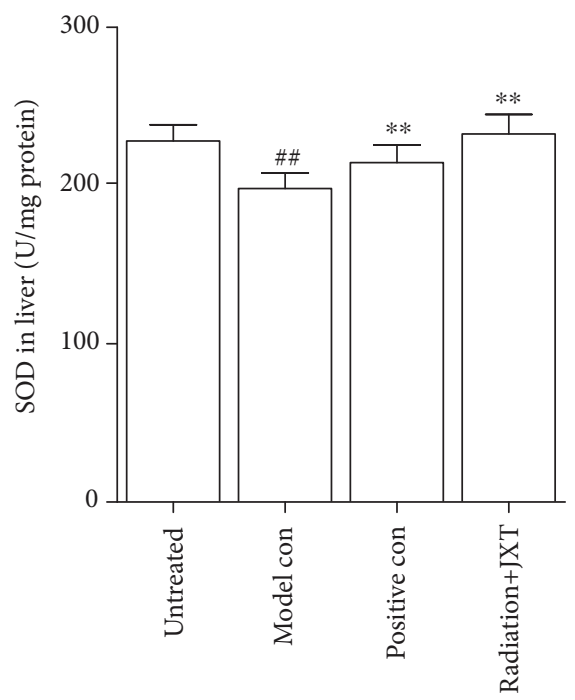

(c)

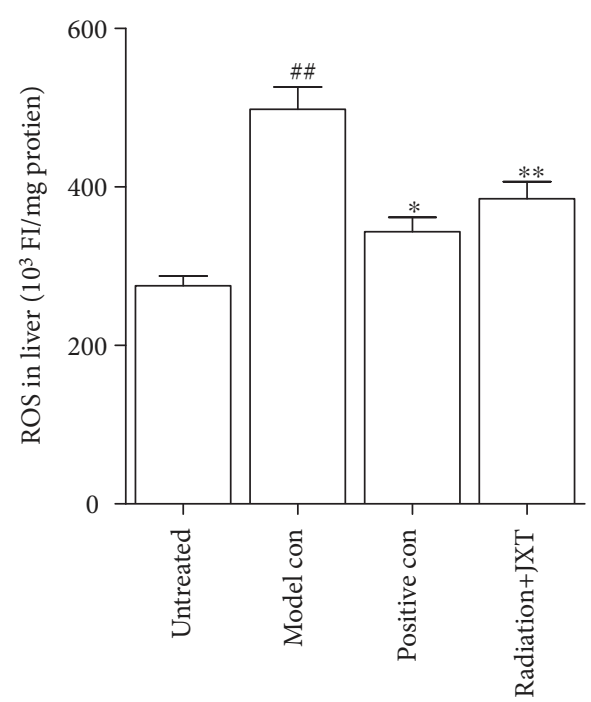

(b)

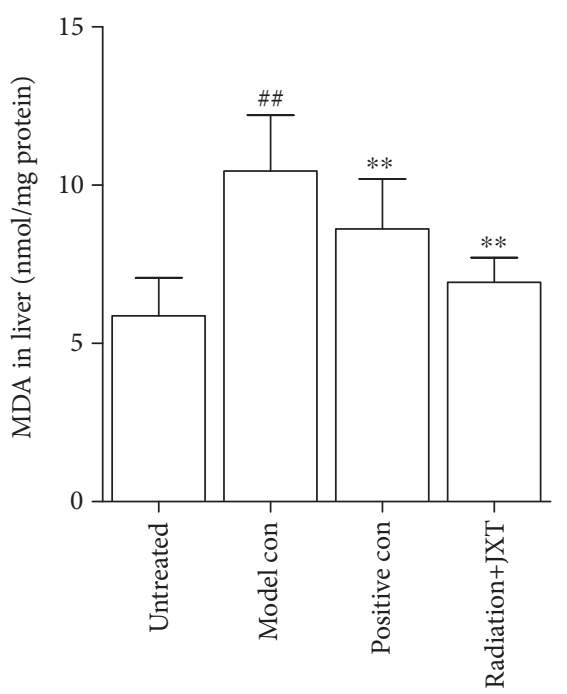

(d)

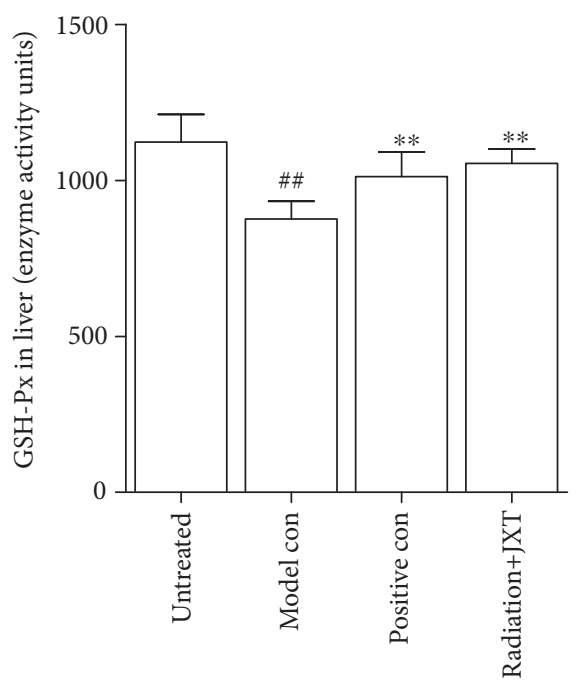

(e)

FIGURE 6: Effect of JXT on the levels of GSH-Px, SOD, and MDA in $\mathrm{Co}^{60}$-irradiated mice. All data were expressed as mean \pm SEM $(n=10)$. ${ }^{\# \#} P<0.01$ when compared with the untreated control group. ${ }^{*} P<0.05 ;{ }^{* *} P<0.01$ when compared with the Co ${ }^{60}$-irradiated group. 


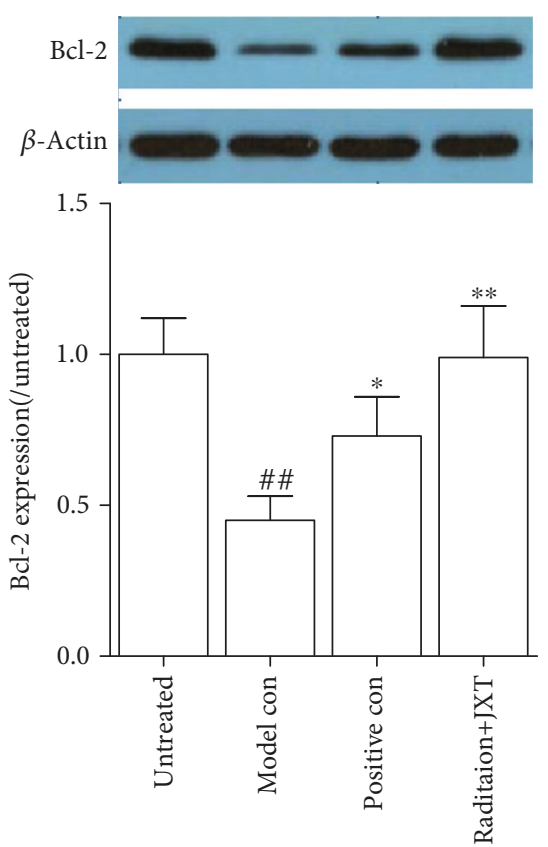

FIGURE 7: Effect of JXT on the expression of Bcl-2 in $\mathrm{Co}^{60}$-irradiated mice. All data were expressed as mean \pm SEM $(n=10)$. ${ }^{\# \# P<0.01}$ when compared with the untreated control group. ${ }^{*} P<0.05$; ${ }^{* *} P<0.01$ when compared with the $\mathrm{Co}^{60}$-irradiated group.

radiation doses. Effects are mediated by the enhancement of extramedullar hematopoiesis in the spleen and a protective effect on the intestinal epithelium [54]. Tea polyphenols, particularly in the combination in TP50 as the radioprotector in mice, have antioxidant potential activity and can reduce inflammatory cytokines especially during the recovery of the hematopoietic system [55]. Beetroot has the potency to preserve bone marrow integrity and stimulate the differentiation of HSCs against ionizing radiation [56].

In our study, JXT has a protective function against hematopoietic dysfunction induced by $\mathrm{Co}^{60}$ radiation. JXT treatment can improve bone marrow damage and ameliorate cellular contents of the bone marrow through stimulating the JAK2/STAT5a signal pathway, thus increasing Bcl-2 expression and blocking bone marrow cell apoptosis in $\mathrm{Co}^{60}$-irradiated mice. The antioxidant capacity of JXT in the liver can be attributed to the regulatory effect on SOD, GSH-Px, and MDA. Therefore, JXT may be a promising radioprotective agent for the suppression of hematopoiesis.

\section{Data Availability}

The data used to support the findings of this study are available from the corresponding author upon request.

\section{Conflicts of Interest}

The authors declare that there is no conflict of interest in the publication of this article.

\section{Authors' Contributions}

Yu-Ning Wang and Xian-Zhe Dong contributed equally to this work.

\section{Acknowledgments}

This work was supported by a grant from the National Natural Science Foundation (no. 81373781).

\section{References}

[1] S. Khan, J. S. Adhikari, M. A. Rizvi, and N. K. Chaudhury, "Radioprotective potential of melatonin against ${ }^{60} \mathrm{Co} \gamma$-rayinduced testicular injury in male C57BL/6 mice," Journal of Biomedical Science, vol. 22, no. 1, article 61, 2015.

[2] E. Park, I. Hwang, J. Y. Song, and Y. Jee, “Acidic polysaccharide of Panax ginseng as a defense against small intestinal damage by wholebody gamma irradiation of mice," Acta Histochemica, vol. 113, no. 1, pp. 19-23, 2011.

[3] J. F. Weiss, "Pharmacologic approaches to protection against radiation-induced lethality and other damage," Environmental Health Perspectives, vol. 105, Supplement 6, pp. 1473-1478, 1997.

[4] T. B. Elliott, N. E. Deutz, J. Gulani et al., "Gastrointestinal acute radiation syndrome in Göttingen minipigs (Sus scrofa domestica)," Comparative Medicine, vol. 64, no. 6, pp. 456463, 2014.

[5] C. Liu, J. Liu, Y. Hao et al., “6, 7, 3’,4'-Tetrahydroxyisoflavone improves the survival of whole-body-irradiated mice via restoration of hematopoietic function," International Journal of Radiation Biology, vol. 93, no. 8, pp. 793-802, 2017.

[6] E. M. Rosen, R. Day, and V. K. Singh, "New approaches to radiation protection," Frontiers in Oncology, vol. 4, p. 381, 2015.

[7] L. Shao, Y. Luo, and D. Zhou, "Hematopoietic stem cell injury induced by ionizing radiation," Antioxidants and Redox Signaling, vol. 20, no. 9, pp. 1447-1462, 2014.

[8] T. A. Davis, T. K. Clarke, S. R. Mog, and M. R. Landauer, "Subcutaneous administration of genistein prior to lethal irradiation supports multilineage, hematopoietic progenitor cell recovery and survival," International Journal of Radiation Biology, vol. 83, no. 3, pp. 141-151, 2007.

[9] M. Liu, H. Tan, X. Zhang et al., "Hematopoietic effects and mechanisms of Fufang E'jiao Jiang on radiotherapy and chemotherapy-induced myelosuppressed mice," Journal of Ethnopharmacology, vol. 152, no. 3, pp. 575-584, 2014.

[10] D. Ewing and S. R. Jones, "Superoxide removal and radiation protection in bacteria," Archives of Biochemistry and Biophysics, vol. 254, no. 1, pp. 53-62, 1987.

[11] P. Cramers, E. E. Verhoeven, A. R. Filon et al., "Impaired repair of ionizing radiation-induced DNA damage in Cockayne syndrome cells," Radiation Research, vol. 175, no. 4, pp. 432-443, 2011.

[12] B. Mukherjee, N. Tomimatsu, K. Amancherla, C. V. Camacho, N. Pichamoorthy, and S. Burma, "The dual PI3K/mTOR inhibitor NVP-BEZ235 is a potent inhibitor of ATM- and DNA-PKCs-mediated DNA damage responses," Neoplasia, vol. 14, no. 1, pp. 34-IN8, 2012. 
[13] C. K. Nair, D. K. Parida, and T. Nomura, "Radioprotectors in radiotherapy," Journal of Radiation Research, vol. 42, no. 1, pp. 21-37, 2001.

[14] R. R. Copp, D. D. Peebles, C. M. Soref, and W. E. Fahl, "Radioprotective efficacy and toxicity of a new family of aminothiol analogs," International Journal of Radiation Biology, vol. 89, no. 7, pp. 485-492, 2013.

[15] D. K. Maurya and C. K. Nair, "Preferential radioprotection to DNA of normal tissues by ferulic acid under ex vivo and in vivo conditions in tumor bearing mice," Molecular and Cellular Biochemistry, vol. 285, no. 1-2, pp. 181-190, 2006.

[16] D. Rades, F. Fehlauer, A. Bajrovic, B. Mahlmann, E. Richter, and W. Alberti, "Serious adverse effects of amifostine during radiotherapy in head and neck cancer patients," Radiotherapy and Oncology, vol. 70, no. 3, pp. 261-264, 2004.

[17] D. Citrin, A. P. Cotrime, F. Hyodo, B. J. Baum, M. C. Krishna, and J. B. Mitchell, "Radioprotectors and mitigators of radiation-induced normal tissue injury," The Oncologist, vol. 15 , no. 4, pp. 360-371, 2010.

[18] S. Pal, C. Saha, and S. K. Dey, "Studies on black tea (Camellia sinensis) extract as a potential antioxidant and a probable radioprotector," Radiation and Environmental Biophysics, vol. 52, no. 2, pp. 269-278, 2013.

[19] Y. Chen, B. Zhu, L. Zhang, S. Yan, and J. Li, "Experimental study of the bone marrow protective effect of a traditional Chinese compound preparation," Phytotherapy Research, vol. 23, no. 6, pp. 823-826, 2009.

[20] R. Arora, D. Gupta, R. Chawla et al., "Radioprotection by plant products: present status and future prospects," Phytotherapy Research, vol. 19, no. 1, pp. 1-22, 2005.

[21] M. H. Whitnall, C. E. Inal, W. E. Jackson, V. L. Miner, V. Villa, and T. M. Seed, "In vivo radioprotection by 5 -androstenediol: stimulation of the innate immune system," Radiation Research, vol. 156, no. 3, pp. 283-293, 2001.

[22] S. J. Bing, M. J. Kim, G. Ahn et al., "Acidic polysaccharide of Panax ginseng regulates the mitochondria/caspase-dependent apoptotic pathway in radiation-induced damage to the jejunum in mice," Acta Histochemica, vol. 116, no. 3, pp. 514-521, 2014.

[23] National Pharmacopoeia Committee, Pharmacopoeia of the People's Republic of China, Part I, China Medical Science Press, Beijing, 2010.

[24] Y. Zhang, L. Guo, L. Duan et al., "Simultaneous determination of 16 phenolic constituents in Spatholobi Caulis by high performance liquid chromatography/electrospray ionization triple quadrupole mass spectrometry," Journal of Pharmaceutical and Biomedical Analysis, vol. 102, pp. 110-118, 2015.

[25] T. Toyama, S. Wada-Takahashi, M. Takamichi et al., "Reactive oxygen species scavenging activity of Jixueteng evaluated by electron spin resonance (ESR) and photon emission," Natural Product Communications, vol. 9, no. 12, pp. 1755-1759, 2015.

[26] D. X. Wang, P. Liu, R. Y. Chen, M. L. Chen, and G. Y. Chen, "Effect of monomers extracted from Spatholobus suberectus Dunn on proliferation of hematopoietic progenitor cells in marrow-depressed mice," Chinese Journal of Tissue Engineering Research, vol. 12, no. 21, article 4166, 2008.

[27] Y. Hu, D. H. Guo, P. Liu et al., "Bioactive components from the tea polyphenols influence on endogenous antioxidant defense system and modulate inflammatory cytokines after total- body irradiation in mice," Phytomedicine, vol. 18, no. 11, pp. 970-975, 2011.

[28] X. Tan, X. Z. Dong, D. H. Guo et al., "Anti-radiation effect and mechanism studies of ethanol extracts from Spatholobus suberectus and its active component catechin," China Journal of Chinese Materia Medica, vol. 41, no. 9, pp. 1718-1724, 2014.

[29] Q. Zou, W. Hong, Y. Zhou et al., "Bone marrow stem cell dysfunction in radiation-induced abscopal bone loss," Journal of Orthopaedic Surgery and Research, vol. 11, no. 1, p. 3, 2016.

[30] S. M. Bentzen, "Preventing or reducing late side effects of radiation therapy: radiobiology meets molecular pathology," Nature Reviews Cancer, vol. 6, no. 9, pp. 702-713, 2006.

[31] Z. C. Ma, Q. Hong, Y. G. Wang et al., "Effects of ferulic acid on hematopoietic cell recovery in whole-body gamma irradiated mice," International Journal of Radiation Biology, vol. 87, no. 5, pp. 499-505, 2011.

[32] A. J. Simonnet, J. Nehmé, P. Vaigot, V. Barroca, P. Leboulch, and D. Tronik-le Roux, "Phenotypic and functional changes induced in hematopoietic stem/progenitor cells after gammaray radiation exposure," Stem Cells, vol. 27, no. 6, pp. 1400 1409, 2009.

[33] P. J. Carey, "Drug-induced myelosuppression: diagnosis and management," Drug Safety, vol. 26, no. 10, pp. 691-706, 2003.

[34] R. Gazit, H. Weissman, and D. J. Rossi, "Hematopoietic stem cells and the aging hematopoietic system," Seminars in Hematology, vol. 45, no. 4, pp. 218-224, 2008.

[35] H. J. Park, J. Li, R. Hannah et al., "Cytokine-induced megakaryocytic differentiation is regulated by genome-wide loss of a USTAT transcriptional program," The EMBO Journal, vol. 35, no. 6, pp. 580-594, 2016.

[36] S. Thomas, K. H. Fisher, J. A. Snowden, S. J. Danson, S. Brown, and M. P. Zeidler, "Methotrexate is a JAK/STAT pathway inhibitor," PLoS One, vol. 10, no. 7, article e0130078, 2015.

[37] C. Vitali, C. Bassani, C. Chiodoni et al., "SOCS2 controls proliferation and stemness of hematopoietic cells under stress conditions and its deregulation marks unfavorable acute leukemias," Cancer Research, vol. 75, no. 11, pp. 2387-2399, 2015.

[38] Z. Wang, G. Li, and K. D. Bunting, "STAT5 N-domain deleted isoforms are naturally occurring hypomorphs partially rescued in hematopoiesis by transgenic Bcl-2 expression," American Journal of Blood Reserach, vol. 4, no. 1, pp. 20-26, 2014.

[39] C. Leroy, N. V. Belkina, T. Long et al., "Caspase cleavages of the lymphocyte oriented kinase prevent ezrin, radixin, and moesin phosphorylation during apoptosis," The Journal of Biological Chemistry, vol. 291, no. 19, pp. 10148-10161, 2016.

[40] K. D. Bunting, H. L. Bradley, T. S. Hawley, R. Moriggl, B. P. Sorrentino, and J. N. Ihle, "Reduced lymphomyeloid repopulating activity from adult bone marrow and fetal liver of mice lacking expression of STAT5," Blood, vol. 99, no. 2, pp. 479487, 2002.

[41] J. W. Snow, N. Abraham, M. C. Ma, N. W. Abbey, B. Herndier, and M. A. Goldsmith, "STAT5 promotes multilineage hematolymphoid development in vivo through effects on early hematopoietic progenitor cells," Blood, vol. 99, no. 1, pp. 95-101, 2002.

[42] H. Schepers, D. van Gosliga, A. T. Wierenga, B. J. L. Eggen, J. J. Schuringa, and E. Vellenga, "STAT5 is required for long-term maintenance of normal and leukemic human stem/progenitor cells," Blood, vol. 110, no. 8, pp. 2880-2888, 2007. 
[43] A. T. Wierenga, E. Vellenga, and J. J. Schuringa, "Maximal STAT5-induced proliferation and self-renewal at intermediate STAT5 activity levels," Molecular and Cellular Biology, vol. 28, no. 21, pp. 6668-6680, 2008.

[44] A. T. Wierenga, H. Schepers, M. A. Moore, E. Vellenga, and J. J. Schuringa, "STAT5-induced self-renewal and impaired myelopoiesis of human hematopoietic stem/progenitor cells involves down-modulation of C/EBPalpha," Blood, vol. 107, no. 11, pp. 4326-4333, 2006.

[45] J. D. Lord, B. C. McIntosh, P. D. Greenberg, and B. H. Nelson, "The IL-2 receptor promotes lymphocyte proliferation and induction of the c-myc, bcl-2, and bcl-x genes through the trans-activation domain of Stat5," Journal of Immunology, vol. 164, no. 5, pp. 2533-2541, 2000.

[46] M. Buitenhuis, B. Baltus, J. W. Lammers, P. J. Coffer, and L. Koenderman, "Signal transducer and activator of transcription 5a (STAT5a) is required for eosinophil differentiation of human cord blood-derived $\mathrm{CD} 34^{+}$cells," Blood, vol. 101, no. 1, pp. 134-142, 2003.

[47] G. Li, K. L. Miskimen, Z. Wang et al., "STAT5 requires the $\mathrm{N}$-domain for suppression of miR15/16, induction of bcl-2, and survival signaling in myeloproliferative disease," Blood, vol. 115, no. 7, pp. 1416-1424, 2010.

[48] H. Oguro and A. Iwama, "Life and death in hematopoietic stem cells," Current Opinion in Immunology, vol. 19, no. 5, pp. 503-509, 2007.

[49] J. Domen and I. L. Weissman, "Hematopoietic stem cells need two signals to prevent apoptosis; BCL-2 can provide one of these, Kitl/c-Kit signaling the other," The Journal of Experimental Medicine, vol. 192, no. 12, pp. 1707-1718, 2000.

[50] J. Domen, K. L. Gandy, and I. L. Weissman, "Systemic overexpression of BCL-2 in the hematopoietic system protects transgenic mice from the consequences of lethal irradiation," Blood, vol. 91, no. 7, pp. 2272-2282, 1998.

[51] K. Takeshita, K. Fujii, K. Anzai, and T. Ozawa, "In vivo monitoring of hydroxyl radical generation caused by $\mathrm{X}$ - ray irradiation of rats using the spin trapping/EPR technique," Free Radical Biology \& Medicine, vol. 36, no. 9, pp. 11341143, 2004.

[52] L. F. Barbisan, C. Scolastici, M. Miyamoto et al., "Effects of crude extracts of Agaricus blazei on DNA damage and on rat liver carcinogenesis induced by diethylnitrosamine," Genetics and Molecular Research, vol. 2, no. 3, pp. 295-308, 2003.

[53] P. G. Wells, Y. Bhuller, C. S. Chen et al., "Molecular and biochemical mechanisms in teratogenesis involving reactive oxygen species," Toxicology and Applied Pharmacology, vol. 207, no. 2, pp. 354-366, 2005.

[54] V. N. Bykov, I. S. Drachev, S. Y. Kraev et al., "Radioprotective and radiomitigative effects of $\mathrm{BP}-\mathrm{C} 2$, a novel lignin-derived polyphenolic composition with ammonium molybdate, in two mouse strains exposed to total body irradiation," International Journal of Radiation Biology, vol. 94, no. 2, pp. 114-123, 2018.

[55] Y. Hu, J. J. Cao, P. Liu et al., "Protective role of tea polyphenols in combination against radiation-induced haematopoietic and biochemical alterations in mice," vol. 25, pp. 1761-1769, 2011.

[56] J. Cho, S. J. Bing, A. Kim et al., "Beetroot (Beta vulgaris) rescues mice from $\gamma$-ray irradiation by accelerating hematopoiesis and curtailing immunosuppression," Pharmaceutical Biology, vol. 55, no. 1, pp. 306-316, 2017. 


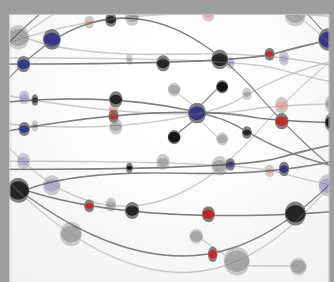

The Scientific World Journal
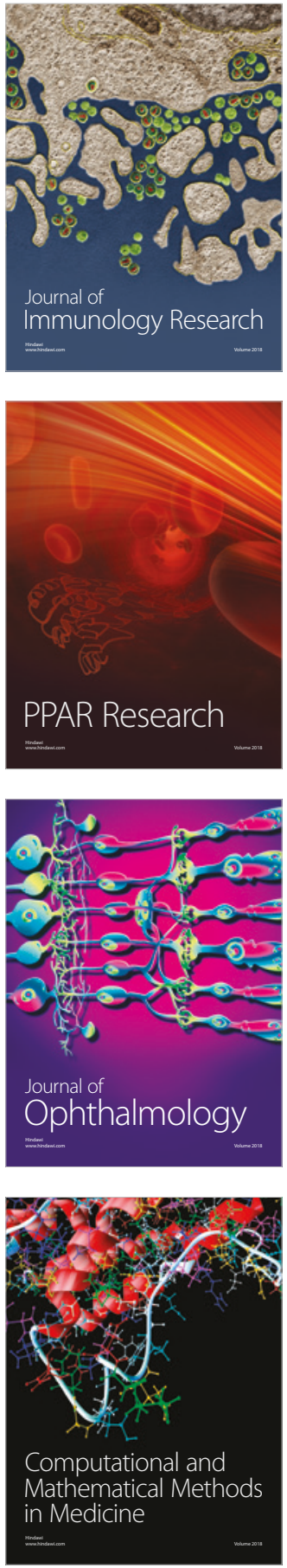

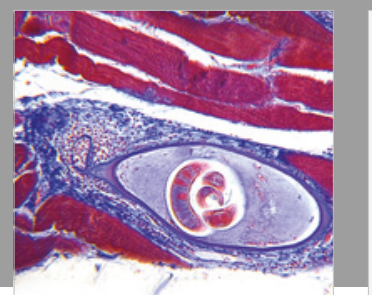

Gastroenterology Research and Practice

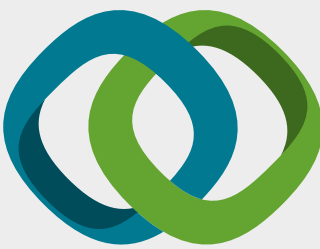

\section{Hindawi}

Submit your manuscripts at

www.hindawi.com
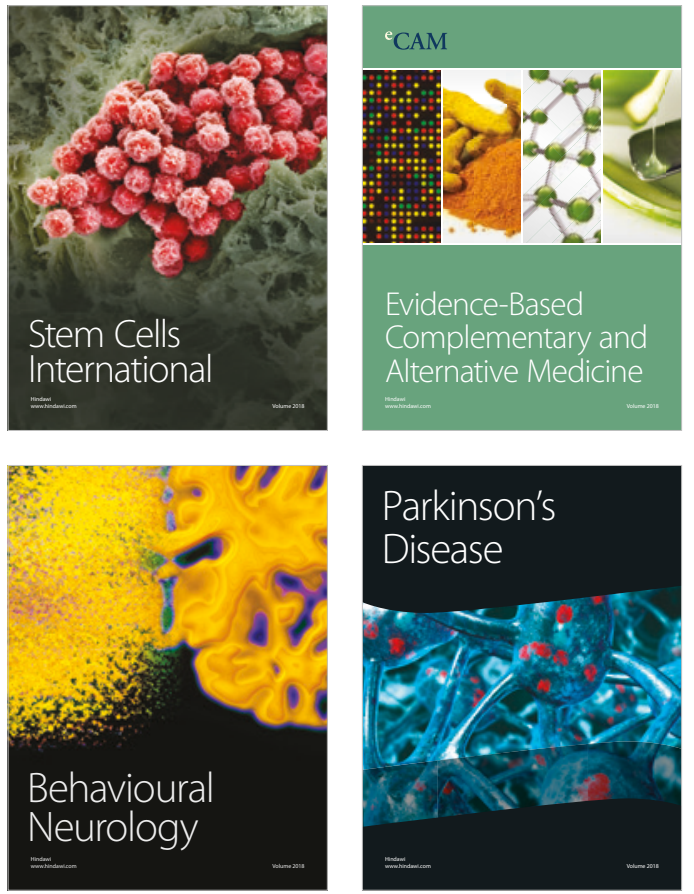

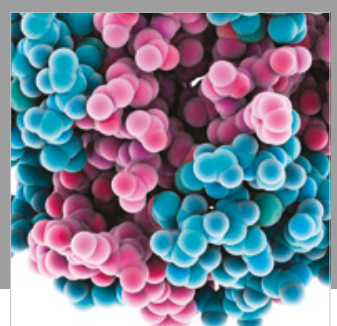

ournal of

Diabetes Research

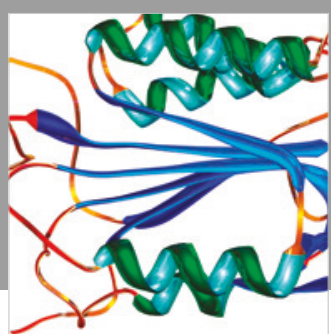

Disease Markers
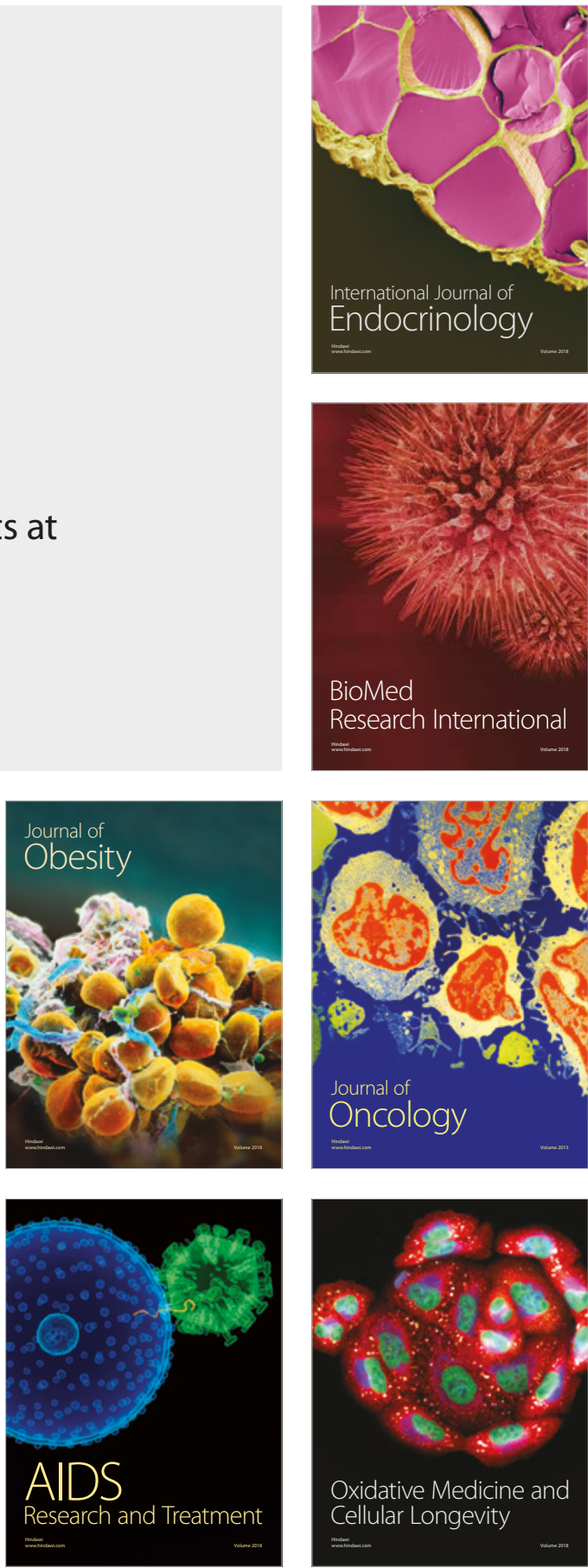